\title{
Cancer Vaccines, Treatment of the Future: With Emphasis on HER2-Positive Breast Cancer
}

\author{
Sandeep Pallerla ${ }^{1}$, Ata ur Rahman Mohammed Abdul ${ }^{2}$, Jill Comeau ${ }^{1}$ and Seetharama Jois ${ }^{1, *}$ \\ 1 School of Pharmaceutical and Toxicological Sciences and School of Clinical Sciences, College of Pharmacy, \\ University of Louisiana Monroe, Monroe, LA 71201, USA; sandeep.pallerla1@gmail.com (S.P.); \\ comeau@ulm.edu (J.C.) \\ 2 Independent Researcher, Wharton, NJ 07885, USA; rahman.nam@gmail.com \\ * Correspondence: jois@ulm.edu; Tel.: +1-318-342-1993
}

Citation: Pallerla, S.; Abdul, A.R.M.; Comeau, J.; Jois, S. Cancer Vaccines, Treatment of the Future: With Emphasis on HER2-Positive Breast Cancer. Int. J. Mol. Sci. 2021, 22, 779. https://doi.org/10.3390/ijms22020779

Received: 4 December 2020 Accepted: 10 January 2021 Published: 14 January 2021

Publisher's Note: MDPI stays neutral with regard to jurisdictional clai$\mathrm{ms}$ in published maps and institutional affiliations.

Copyright: (C) 2021 by the authors. Licensee MDPI, Basel, Switzerland. This article is an open access article distributed under the terms and conditions of the Creative Commons Attribution (CC BY) license (https:// creativecommons.org/licenses/by/ $4.0 /)$.

\begin{abstract}
Breast cancer is one of the leading causes of death in women. With improvements in early-stage diagnosis and targeted therapies, there has been an improvement in the overall survival rate in breast cancer over the past decade. Despite the development of targeted therapies, tyrosine kinase inhibitors, as well as monoclonal antibodies and their toxin conjugates, all metastatic tumors develop resistance, and nearly one-third of HER2+ breast cancer patients develop resistance to all these therapies. Although antibody therapy has shown promising results in breast cancer patients, passive immunotherapy approaches have limitations and need continuous administration over a long period. Vaccine therapy introduces antigens that act on cancer cells causing prolonged activation of the immune system. In particular, cancer relapse could be avoided due to the presence of a longer period of immunological memory with an effective vaccine that can protect against various tumor antigens. Cancer vaccines are broadly classified as preventive and therapeutic. Preventive vaccines are used to ward off any future infections and therapeutic vaccines are used to treat a person with active disease. In this article, we provided details about the tumor environment, different types of vaccines, their advantages and disadvantages, and the current status of various vaccine candidates with a focus on vaccines for breast cancer. Current data indicate that therapeutic vaccines themselves have limitations in terms of efficacy and are used in combination with other chemotherapeutic or targeting agents. The majority of breast cancer vaccines are undergoing clinical trials and the next decade will see the fruitfulness of breast cancer vaccine therapy.
\end{abstract}

Keywords: vaccine; breast cancer; HER2; therapeutic vaccine; cell-based vaccine; DNA-based vaccine

\section{Introduction}

Cancer is the second most common cause of death worldwide. According to the WHO, in 2018, approximately 9.6 million people died from cancer. Among the different types of cancers, lung, breast, prostate, and colorectal cancers are the most common. Each of these cancers contain molecularly defined subtypes and therefore vary in terms of incidence and prognosis. Breast cancer is the second most common reason for cancer-related fatalities in the United States in spite of the various recent improvements in diagnosis, prognosis, and treatment [1,2]. In the United States, approximately one in eight women during their lifetime will develop invasive breast cancer. Based on the data published in 2020, it is projected that about 276,480 women and 2000 men will be diagnosed with invasive breast cancer, and approximately 48,530 new cases of non-invasive (in situ) breast cancer will occur [3]. Breast cancer is defined as asymmetrical growth and proliferation of cells in the breast tissue [4]. In the last few decades, there has been an appreciable improvement in the treatment of breast cancer patients; however, there is a need to develop new, effective treatment strategies with minimal adverse effects.

The four major molecular subtypes of breast cancer include luminal A, luminal B, HER2-enriched, and basal-like triple-negative. This is determined by the expression of 
hormones (both estrogen and progesterone) and HER2 receptors. Triple-negative breast cancer (TNBC) is a condition where patients do not express the genes for estrogen receptor (ER), progesterone receptor (PR), and Her2/neu, thus making it difficult to treat TNBC patients. Along with HER2-enriched cancers, there is a subset of luminal B breast cancers that has HER2 overexpression [5-7]. HER2 belongs to the EGFR family receptors that play a crucial role in the pathogenesis of various cancers such as lung, breast, ovarian, and renal cancer [8]. The EGFR family includes 4 types of receptors; HER1 (EGFR), HER2, HER3, and HER4. Amongst these four receptors, HER2 receptors are overexpressed in different types of cancers. In about 20 to $30 \%$ of breast cancer patients, HER2 receptors are found to be overexpressed [9]. The HER2 overexpression is associated with enhanced tumor growth, poorer response to traditional chemotherapy, and overall decreased survival [10]; thus, researchers have focused on the development of HER2-based targeted therapies.

Treatment of HER2-positive breast cancer with chemotherapeutic agents alone elicited a poor response [11-15]. The discovery of tumor-associated antigens (TAA) has facilitated the emergence of immunotherapy. Immunotherapy with respect to cancer can be defined as the interference of the immune system for the mitigation of cancers [16]. Monoclonal antibodies that have anti-tumor properties were developed against the HER2 receptor. The intervention of the tumor growth via monoclonal antibodies falls under the category of passive immunity $[17,18]$. Trastuzumab was the first FDA-approved monoclonal antibody recommended for treating HER2-positive metastatic breast cancer. It causes anti-tumor effects through various mechanisms such as induction of apoptosis, induction of cell cycle arrest, antibody-dependent cell-mediated cytotoxicity (ADCC), inhibition of HER2 extracellular domain shedding, and inhibition of downstream signal transduction pathways [19-21].

Additionally, monoclonal antibodies and their conjugates such as pertuzumab, trastuzumab emtansine (T-DM1), and fam-trastuzumab deruxtecan were also approved by the FDA for treating HER2-positive breast cancer patients [22]. In the EMILIA study, T-DM1 exhibited improved survival for the second-line treatment of metastatic HER2-positive breast cancer compared to the existing standard therapy, capecitabine with lapatinib, a HER2 tyrosine kinase inhibitor [23]. T-DM1, compared to trastuzumab, has also been shown to improve disease-free survival after surgery in those patients who have residual cancer after receiving neoadjuvant chemotherapy in the KATHERINE trial [24]. Fam-trastuzumab was studied in a phase II clinical trial, which showed promising efficacy results in those patients diagnosed with metastatic HER2-positive breast cancer who failed T-DM1 [25,26]. Using monoclonal antibodies for cancer therapy is an effective and efficient strategy to treat breast cancer, but it has its own drawbacks such as the cost, treatment duration and frequency, resistance, and tolerance. Furthermore, these monoclonal antibodies show temporary disease control once the tumor is metastasized; hence, there is a need for therapies that elicit anti-tumor effects on metastatic tumors. Due to the aggressiveness of HER2-positive breast cancer, there is also a need to minimize the chance of relapse in those with a curable disease.

Despite the development of targeted therapies, tyrosine kinase inhibitors, as well as monoclonal antibodies and their toxin conjugates, all metastatic tumors develop resistance, and nearly one-third of HER2+ breast cancer patients develop resistance to all these therapies $[7,27]$. Thus, passive immunotherapy approaches have limitations and need continuous administration over a long period. On the other hand, a vaccine which introduces antigens acts on the cancer cells, causing prolonged activation of the immune system. Vaccines have a number of advantages compared to chemotherapy and monoclonal antibodies. Potential cancer relapse can be averted by activating long-term immunological memory with an effective vaccine that can protect against various tumor antigens. Vaccines are not required to be administered frequently and, historically, vaccines are comparatively safer than chemotherapy [28]. The first attempt to use a cancer vaccine was more than a century ago. In 1902, von Leyden and Blumenthal used an autologous tumor cell suspension as a vaccine and treatment for cancer patients [29]. During the 1950s, animal studies revealed that cancer tumors induced in mice by chemicals were immunogenic. Since then, there 
have been attempts to design a vaccine for cancer. Among breast cancer types, HER2positive and triple-negative breast cancer (TNBC) subtypes are most immunogenic [30]. Thus, for these types of cancer, activating the patient's immune system is a promising approach. Although overall progress is slow and clinical translation of this knowledge faced challenges, preclinical studies provided strong support for cancer vaccines, and there are some success stories.

Cancer vaccines can be broadly classified as preventive and therapeutic. Preventive vaccines are used to ward off any future infections, whereas therapeutic vaccines are used to treat a person with active disease [28]. Sipuleucel-T (Provenge) was the first therapeutic cancer vaccine approved by the FDA in the year 2010 for the treatment of metastatic castrate-resistant prostate cancer (mCRPC) [31]. Table 1 provides a list of FDA-approved preventive cancer vaccines. In this article, we will focus on therapeutic vaccines. Currently, a couple of therapeutic vaccines are approved by the FDA, which are listed in Table 2. Ongoing clinical trials of therapeutic vaccines are listed in Table 3. The success of these vaccines depends on several factors, including understanding the tumor microenvironment, strategies for reactivating the immune system utilizing different vaccine candidates, and vaccine formulations. Numerous review articles about cancer vaccines have been published over the past five years [30,32-45]. In this article, we provided details about the tumor environment, different types of vaccines, their advantages and disadvantages, and the current status of various vaccine candidates with a focus on vaccines for breast cancer.

Table 1. List of FDA-approved preventive cancer vaccines.

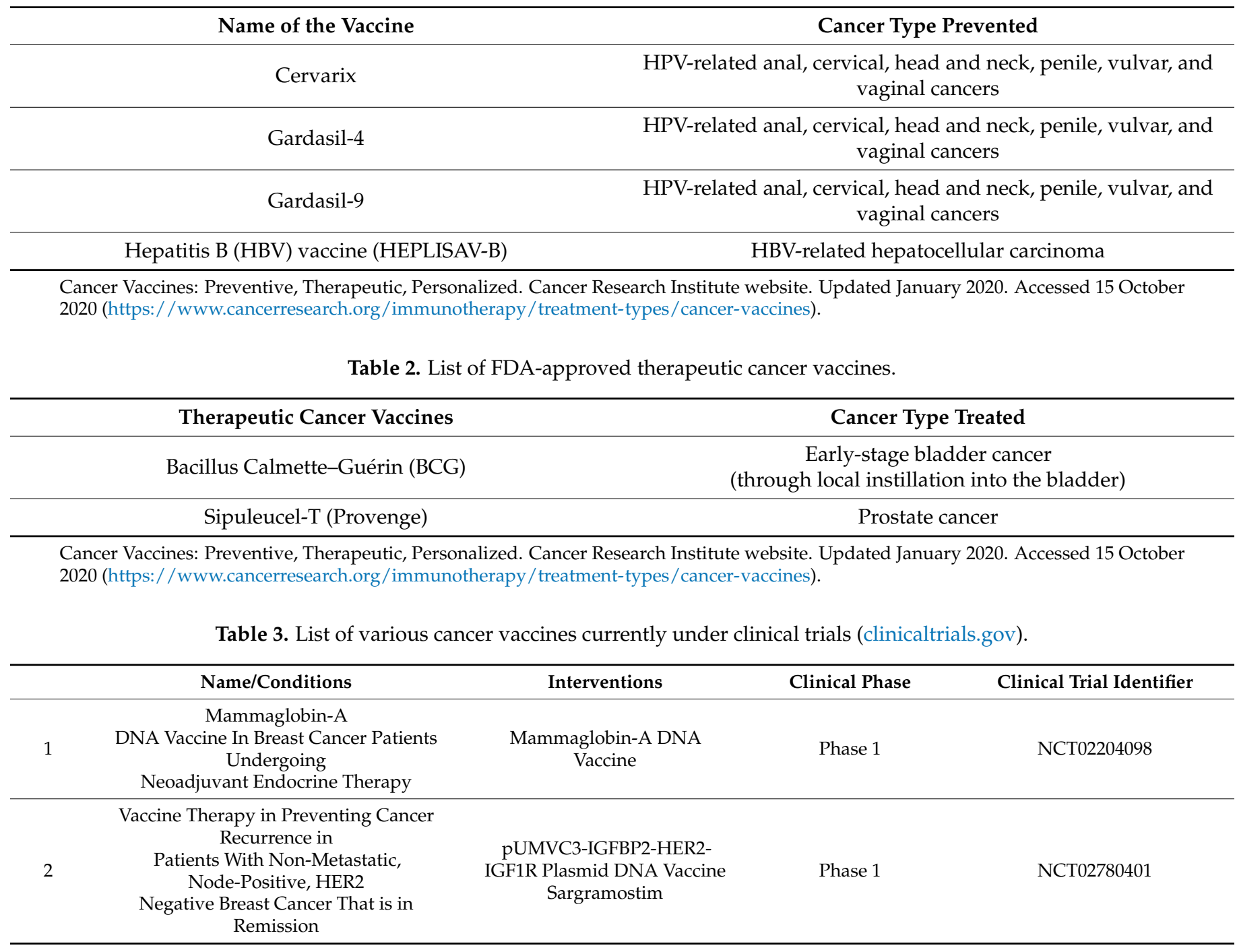


Table 3. Cont

\begin{tabular}{|c|c|c|c|c|}
\hline & Name/Conditions & Interventions & Clinical Phase & Clinical Trial Identifier \\
\hline 3 & $\begin{array}{c}\text { A Study to Evaluate Concurrent } \\
\text { VRP-HER2 Vaccination } \\
\text { and Pembrolizumab for Patients With } \\
\text { Breast Cancer }\end{array}$ & $\begin{array}{c}\text { VRP-HER2 } \\
\text { Pembrolizumab }\end{array}$ & Phase 2 & NCT03632941 \\
\hline 4 & $\begin{array}{l}\text { HER2 Directed Dendritic Cell Vaccine } \\
\text { During } \\
\text { Neoadjuvant Therapy of HER2+Breast } \\
\text { Cancer }\end{array}$ & $\begin{array}{c}\text { Dendritic Cell Vaccine } \\
\text { (DC1) } \\
\text { Neoadjuvant } \\
\text { Chemotherapy }\end{array}$ & Phase 1 & NCT03387553 \\
\hline 5 & $\begin{array}{c}\text { Vaccine Therapy in Treating Patients } \\
\text { With HER2- } \\
\text { Negative Stage III-IV Breast Cancer }\end{array}$ & $\begin{array}{l}\text { CD105/Yb- } \\
\text { 1/SOX2/CDH3/ } \\
\text { MDM2-polyepitope } \\
\text { Plasmid DNA } \\
\text { Vaccine }\end{array}$ & Phase 1 & NCT02157051 \\
\hline 6 & $\begin{array}{l}\text { HER2 Pulsed DC Vaccine to Prevent } \\
\text { Recurrence of } \\
\text { Invasive Breast Cancer } \\
\text { Breast Cancer }\end{array}$ & $\begin{array}{l}\text { HER2 pulsed Dendritic } \\
\text { Cell Vaccine }\end{array}$ & Phase 1 & NCT02063724 \\
\hline 7 & $\begin{array}{c}\text { HER2 Pulsed DC Vaccine to Prevent } \\
\text { Recurrence } \\
\text { of Invasive Breast Cancer Post } \\
\text { Neoadjuvant } \\
\text { Chemotherapy } \\
\text { Breast Cancer }\end{array}$ & $\begin{array}{l}\text { HER2 pulsed Dendritic } \\
\text { Cell Vaccine }\end{array}$ & Phase 1 & NCT02061423 \\
\hline 8 & $\begin{array}{c}\text { QUILT-3.013: Study of Ad5 [E1-, } \\
\text { E2b-]-HER2/Neu } \\
\text { Vaccine (ETBX-021) in Subjects With } \\
\text { Unresectable } \\
\text { Locally Advanced or Metastatic } \\
\text { HER2-Expressing } \\
\text { Breast Cancer } \\
\text { Cancer }\end{array}$ & ETBX-021 & Phase 1 & NCT02751528 \\
\hline 9 & $\begin{array}{c}\text { Xenogeneic HER2/Neu DNA } \\
\text { Immunization for Patients } \\
\text { With Metastatic and High-Risk Breast } \\
\text { Cancer. }\end{array}$ & $\begin{array}{l}\text { MAB HER } 2 \\
\text { (HERCEPTIN) }\end{array}$ & Phase 1 & NCT00393783 \\
\hline 10 & $\begin{array}{l}\text { Immune Response and Potential } \\
\text { Booster for Patients } \\
\text { Who Have Received HER2-pulsed } \\
\text { DC1 }\end{array}$ & HER2 DC1 Vaccine & Phase 2 & NCT03630809 \\
\hline 11 & $\begin{array}{c}\text { A Vaccine (H2NVAC) Before Surgery } \\
\text { for the Treatment } \\
\text { of HER2-Expressing Ductal } \\
\text { Carcinoma In Situ }\end{array}$ & $\begin{array}{l}\text { Granulocyte-Macrophage } \\
\text { Colony-Stimulating Factor } \\
\text { Multi-epitope HER2 } \\
\text { Peptide Vaccine H2NVAC }\end{array}$ & Phase 1 & NCT04144023 \\
\hline 12 & $\begin{array}{l}\text { A Phase I/II Trial of HER2/Neu } \\
\text { Pulsed DC1 Vaccine } \\
\text { Combined With Trastuzumab for } \\
\text { Patients With DCIS } \\
\text { Breast Cancer }\end{array}$ & $\begin{array}{l}\text { HER2 pulsed DC1 } \\
\text { Drug: trastuzumab } \\
\text { Drug: pertuzumab }\end{array}$ & $\begin{array}{l}\text { Phase } 1 \\
\text { Phase } 2\end{array}$ & NCT02336984 \\
\hline 13 & $\begin{array}{c}\text { Vaccine Therapy With Sargramostim } \\
\text { (GM-CSF) in } \\
\text { Treating Patients With HER2 Positive } \\
\text { Stage III-IV Breast } \\
\text { Cancer or Ovarian Cancer }\end{array}$ & $\begin{array}{l}\text { pNGVL3-hICD vaccine } \\
\text { Biological: sargramostim }\end{array}$ & Phase 1 & NCT00436254 \\
\hline
\end{tabular}


Table 3. Cont.

\begin{tabular}{|c|c|c|c|c|}
\hline & Name/Conditions & Interventions & Clinical Phase & Clinical Trial Identifier \\
\hline 14 & $\begin{array}{l}\text { TPIV100 and Sargramostim for the } \\
\text { Treatment of HER2 } \\
\text { Positive, Stage II-III Breast Cancer in } \\
\text { Patients With } \\
\text { Residual Disease After Chemotherapy } \\
\text { and Surgery }\end{array}$ & $\begin{array}{c}\text { Pertuzumab } \\
\text { Sargramostim } \\
\text { Trastuzumab } \\
\text { Trastuzumab Emtansine } \\
\text { Vaccine Therapy }\end{array}$ & Phase 2 & NCT04197687 \\
\hline 15 & $\begin{array}{c}\text { Vaccine Therapy in Treating Patients } \\
\text { With Stage IV } \\
\text { HLA-A2 and HER2 Positive Breast or } \\
\text { Ovarian Cancer } \\
\text { Receiving Trastuzumab }\end{array}$ & $\begin{array}{l}\text { HER2/neu Peptide } \\
\text { Vaccine }\end{array}$ & $\begin{array}{l}\text { Phase } 1 \\
\text { Phase } 2\end{array}$ & NCT00194714 \\
\hline 16 & $\begin{array}{c}\text { Vaccine to Prevent Recurrence in } \\
\text { Patients With HER2 } \\
\text { Positive Breast Cancer }\end{array}$ & $\begin{array}{c}\text { DC1 Vaccine } \\
\text { WOKVAC Vaccine }\end{array}$ & Phase 2 & NCT03384914 \\
\hline 17 & $\begin{array}{l}\text { Phase II Trial of Combination } \\
\text { Immunotherapy With } \\
\text { NeuVax and Trastuzumab in } \\
\text { High-risk HER2+ Breast } \\
\text { Cancer Patients }\end{array}$ & $\begin{array}{l}\text { NeuVax vaccine } \\
\text { Drug: Trastuzumab } \\
\text { Drug: GM-CSF }\end{array}$ & Phase 2 & NCT02297698 \\
\hline 18 & $\begin{array}{c}\text { Folate Receptor Alpha Peptide } \\
\text { Vaccine With GM-CSF in } \\
\text { Patients With Triple-Negative Breast } \\
\text { Cancer }\end{array}$ & $\begin{array}{l}\text { Low dose FR\# vaccine } \\
\text { Drug: Cyclophosphamide } \\
\text { High dose FR\# vaccine }\end{array}$ & Phase 2 & NCT02593227 \\
\hline
\end{tabular}

\section{Tumor Microenvironment and Its Modulation for Effective HER2 Vaccines}

The human immune system is a complex network containing a variety of cells that effectively fight against pathogens and TAAs [46]. These TAAs are presented to the immune system in two ways; directly by the tumor cells and/or by antigen-presenting cells (APCs). In the process, the TAAs are degraded to immunogenic peptides and then presented to $\mathrm{T}$ cells via the major histocompatibility complex (MHC), eventually resulting in an immune response. However, this process is suppressed in the tumor microenvironment. The microenvironment around the tumor plays a significant role in its progression and control of cancer growth [47]. The tumor microenvironment is rich in molecules such as cyclooxygenase 2 (COX-2), vascular endothelial growth factor (VEGF), interleukin-6, interleukin-10, stem cell factor-1, macrophage-colony stimulating factor (M-CSF), and transforming growth factor (TGF- $\beta$ ) that are involved in the suppression of immune system functions and promote activation, invasion, and metastasis of tumors [48]. Furthermore, several mechanisms have been reported to be involved in immunosuppression, including expansion of myeloidderived suppressor cells (MDSCs) [49], tumor-associated macrophages, and other myeloid cells [50,51], perturbation of cytokine networks [52], changes in host metabolism [53], and the production of amino acid-degrading enzymes and indoleamine 2,3-dioxygenase 1 (IDO1) [54]. Costimulatory signals such as B7, CD40, 4-1BBL [55], and OX40L [56] that are involved in the activation of $\mathrm{T}$ cells are absent in tumors of epithelial origin. Dendritic cells are also suppressed, resulting in a poor immune response against tumors [57]. These compounded immunological anomalies can lead to altered DC and T cell function and result in an impaired immune response against tumor cells [58]. The identification of the various causes for the immunosuppression and discovery of various molecules and TAAs (HER2, carbohydrate antigens, telomerase reverse transcriptase (hTERT), and mucin-1 (MUC-1)) led to the development of various strategies for the treatment of breast cancers by activating the immune system [46]. Research has demonstrated that patients with HER2-positive cancers have HER2 antibodies, prompting researchers to focus on a strategy to enhance patients' immunity for the treatment of HER2-positive breast cancers [59]. 
Several strategies for developing vaccines against cancer are being investigated, including the use of peptides, proteins, APCs, tumor lysates, tumor cells, DNA, mRNA, and viral vectors [47].

\section{Peptide-Based Cancer Vaccines}

In the past decade, peptide-based vaccines have attracted a lot of attention for their potential use against cancer. There is a wealth of information about peptide-based cancer vaccine therapies in the literature [60-62]. Peptide-based cancer vaccines offer several possible advantages, including ease of synthesis, being cost-effective compared to other cancer-based vaccines, tolerable side effects, and safety. Additionally, computer-based algorithms can be applied while screening amino acid sequences for candidates with MHC class I-restricted peptide epitopes of the TAAs, and these candidates can be tested experimentally for their antigen-specific immune response.

$\mathrm{T}$ cell-based vaccines induce immune responses by delivering synthetic $\mathrm{T}$ cell epitopes into the body. $\mathrm{T}$ cell-based vaccines were originally studied to subsequently activate cytotoxic T lymphocytes (CTLs). Both CTLs and T helper cells were activated using short peptides; however, now, longer peptides are used to activate both CTLs and Thelper cells. These peptides, when injected into a patient, bind to human leukocyte antigen (HLA) classes I and II of the APCs and form a peptide-HLA complex. This complex, when recognized by CTLs, is activated and proliferates. This results in an immune response, thereby attacking cancer cells [63].

On the other hand, B cell-based vaccines induce immune response via the B cell epitope of the specific TAA/tumor-specific antigen (TSA). In this type of vaccine, antibodies are produced and bind to the antigen of interest. The major advantage is MHC-I molecules are not involved in the generation of a response. Even if MHC-I molecules are downregulated by tumor evasion mechanisms, it will not affect the immune response against tumors [63].

The first clinical trials for the peptide-based vaccines were performed in the year 1990 by using a single epitope-peptide. E75 is a 9 amino acid-long peptide derived from the HER2 receptor and is predicted to bind HLA-A2, thus activating CTLs [64-66]. E75 is the most studied cancer vaccine. Several phase I studies were conducted by injecting peptide as a vaccine by mixing it with different immunoadjuvants. Results show that the vaccine is safe and is able to induce peptide-specific CTLs. Later, additional studies were evaluated by combining E75 with a granulocyte-macrophage colony-stimulating factor (GM-CSF) in 187 node-positive and high-risk node-negative breast cancer patients. Results concluded that the 5-year disease-free survival (DFS) was $89.7 \%$ for those who received E75 and $80.2 \%$ in those who received placebo, respectively. In phase III clinical trials, E75 with the adjuvant GM-CSF vaccine (Neuvax) was evaluated in patients with low HER2 expression (IHC $1+/ 2+$ ). This combination was found to have no difference between placebo and Neuvax in DFS events resulting in the termination of clinical trials; however, future studies should be done combined with other medications [67].

GP2, an immunogenic peptide, a fragment of the transmembrane domain of HER2 (654-662), is a 9 amino acid-long peptide (IISAVVGIL) vaccine. It binds to the HLA-A2 molecule, but with lesser affinity compared to E75 [68], and activates CTLs. The phase I clinical trial suggested that GP2 with GM-CSF is safe and tolerated in patients with lymph node-negative breast cancer [68]. The phase II clinical trials were conducted in the clinically disease-free patients with node-positive and high-risk node HER2-expressing tumors (immunohistochemistry (IHC) 1+-3+). Results did not show a significant difference in response to the vaccine compared to the control groups in the rate of reoccurrence; however, it can be inferred from the trials that the vaccine is safe to be injected. Furthermore, there was a trend toward clinical significance in patients with HER2-overexpressed tumors [69].

AE37 is a peptide with 15 amino acids which activates CD4+ Thelper cell $\left(T_{h}\right)$ lymphocytes [70]. In phase I clinical trials conducted on patients with different HER2-expressed breast cancer of all stages and IHC of $1+$ to $3+$, it was demonstrated that the vaccine has no 
significant effect on the DFS rate in patients with high HER2-expressing receptors on their breast tissue [69].

Limited research has been performed on B cell peptide vaccines. The success of trastuzumab as a therapeutic agent for breast cancer has led to an interest in B cell peptide vaccines. A phase I study was performed in metastatic breast cancer patients with three HER2 peptides derived from the HER2 receptor formulated with influenza virosomes. The study results showed that the vaccine is safe. In about $80 \%$ of the patients, it was found to be immunogenic. The antibodies developed in the patients can be compared to those of the current antibody-based HER2 treatment drugs [63,71]. Another phase I clinical trial for the vaccine containing two HER2 B cell epitomes that are binding sites for trastuzumab and pertuzumab was performed [72]. The aim of the vaccine is to overcome the resistance associated with trastuzumab and pertuzumab. This study was performed on 49 patients diagnosed with metastatic and/or recurrent solid tumors and showed that the vaccine is safe, elicits anti-tumor effects, and has the ability to overcome the resistance associated with trastuzumab and pertuzumab. Thus, this vaccine could be used as an alternative to monoclonal antibodies.

Even though peptide-based vaccines have several advantages, they do have some limitations. Peptide-based vaccines need a suitable adjuvant in order to produce an efficient immune response. The immune response is limited to a few epitopes, which results in a limited response against tumor cells. Other limitations include secondary structure, enzymatic stability, short half-life, and high rates of elimination [73-75]. There are examples of attempts to improve the balanced induction of both CD8 and CD4 T cells by using multivalent synthetic long peptides (SLPs) containing both MHC class I and class II epitopes [76].

\section{Protein-Based Cancer Vaccines}

While most of the attempts made using peptide-based vaccines have not shown a significant breakthrough compared to injecting a whole protein into the body, it has many theoretical advantages that may overcome the disadvantages associated with peptide-based vaccines. The major advantage of utilizing a whole protein (HER2 intra- or extracellular domains) as vaccines is that it contains both HLA class I and II epitopes; hence, specific HLA restrictions can be avoided. Long polypeptides or protein-based vaccines can significantly activate T cells resulting in a heightened immune response and superior $\mathrm{T}$ cell activation $[77,78]$.

Unlike peptide-based vaccines, the prospect of utilizing protein-based vaccines has not been explored extensively. The first clinical study was performed with the HER2 intracellular domain (a fragment sequence from 676 to 1255 of the full-length HER2/neu) with the aim to evaluate whether the vaccine can generate immunogenicity. In this study, 29 patients who had HER2-positive breast or ovarian cancer and were in remission after traditional treatment were injected with different doses $(25,150$, and $900 \mu \mathrm{g})$ of the vaccine. Results showed that the vaccine was well-tolerated, and HER2 ICD-specific T cell immunity developed in approximately $89 \%$ of the patients who completed the whole vaccine schedule. About $82 \%$ of the patients developed HER2/neu-specific immunoglobulin G antibody immunity. Furthermore, there were no reports of grade 2-4 toxic events [79]. Additionally HER-2/neu helper peptide based vaccines have been found to be effective in BC patients [80] A study was performed by Hamilton et al. [81] with the aim to evaluate immunogenicity, safety, and effect of the anti-HER2 protein. The vaccine, dHER2 [82], is a recombinant protein consisting of an extracellular domain (ECD) and a fragment of the intracellular domain (ICD) of HER2 combined with the adjuvant AS15. The twelve patients enrolled in the study with trastuzumab-refractory HER2-overexpressing metastatic breast cancer received the vaccine and oral lapatinib. Results indicated that all the patients in the study were prompted with the anti-HER2-specific antibody, and there were no reports of cardiotoxicity. Reports also showed the overall survival at 300 days was found to be $92 \%$ ( $95 \%$ CI: $77 \%-100 \%)$, suggesting a potential survival benefit in patients with HER2-overexpressing breast cancers refractory to trastuzumab [81]. 


\section{Whole Cell-Based Vaccines}

Most of the non-cell-based cancer vaccines are designed using a single tumor-associated antigen (TAA), and a major problem in developing vaccine therapies is the selection of an appropriate TAA that would maximize the immune response. Immunizing BC patients with tumor cells isolated from the patient can circumvent the problems associated with antigen selection. The principle behind this strategy is that a tumor cell harbors a wide variety of TAAs that would help in inducing a strong immune response. Tumor cells isolated from patients are used to develop autologous tumor cell-based vaccines (ATCVs). ATCVs consist of both characterized and uncharacterized TAAs that could help in launching a polyclonal response against a wide variety of tumor cells [83]. However, the process of developing ATCVs for individual patients is complex and expensive; hence, allogeneic tumor cell lines can be used as an alternative for the development of cell-based vaccines [84]. Whole cell-based vaccines can also be manipulated to express cytokines or chemokines to maximize the immune response against the injected whole-cell vaccine [85]. The addition of the granulocyte-macrophage colony-stimulating factor (GM-CSF) to a whole tumor cell vaccine stimulates the migration of DCs, T cells, eosinophils, and macrophages to the site of vaccination [85].

Two ongoing and three completed clinical trials have explored the efficacy of ATCVs in BC patients. In a completed study, 121 patients diagnosed with breast cancer, metastatic breast cancer, or ovarian cancer were vaccinated with an autologous breast tumor cell infected with Newcastle disease virus (NDV). The 4-year overall survival (OS) was $96 \%$, thus validating the efficacy of the vaccine [86]. In a different study, 42 breast cancer patients were vaccinated with a vaccine mix consisting of autologous and allogenic breast tumor cells, three TAAs combined with GM-CSF and IL-2 [87]. Post-vaccination, a significant increase in lymphocyte proliferation was observed in $57-100 \%$ of the patients enrolled in the study [87]. Elliott et al. enrolled 37 breast cancer patients with suppressed immunity into a study and vaccinated them with a whole-cell vaccine consisting of autologous and allogenic tumor cells supplemented with adjuvants. Post-vaccination, it was observed that the 10-year survival of vaccinated patients with depressed immunity increased significantly compared to the historic controls of unvaccinated patients [88]. In the above three clinical studies, the whole cell-based vaccines were found to be safe and did not elicit any significant toxicity. Currently, two active clinical studies sponsored by the Dana-Faber Cancer Institute are in progress (NCT00317603, Vaccination with Autologous Breast Cancer Cells Engineered to Secrete Granulocyte-Macrophage Colony-Stimulating Factor (GM-CSF) in Metastatic Breast Cancer Patients, available at: clinicaltrials.gov; NCT00880464, Autologous Vaccination with Lethally Irradiated, Autologous Breast Cancer Cells Engineered to Secrete GM-CSF in women with Operable Breast Cancer, available at: clinicaltrials.gov). A detailed review of the clinical and preclinical studies related to ATCVs and breast cancer therapy can be found elsewhere [83]. The aforementioned clinical studies have demonstrated that ATCVs can be used as a highly effective and safe vaccine in BC patients. However, one disadvantage of using ATCVs is the high variability in the vaccine and the tedious vaccine manufacturing process [83].

ATCV manufacturing is dependent upon a patient's specific tumor tissue. Therefore, it can be considered personalized medicine. The ATCVs may not have broad-spectrum application that is expected from a traditional vaccine. Allogenic vaccines are similar to ATCVs except that the source material is obtained from a different individual or from well-established cancer cell lines that are known to express specific TAAs [89]. A phase I clinical trial involving 28 metastatic BC patients was carried out to investigate the efficacy of a combination therapy using an allogeneic vaccine along with chemotherapy [90]. The allogeneic vaccine was formulated with TAAs obtained from two Her2/neu positive adenocarcinoma breast cancer cell lines SKBR3 and T47D. This vaccine was administered either alone or in combination with cyclophosphamide (CY) and doxorubicin (DOX) [91]. This study demonstrated that the vaccine alone or along with low-dose chemotherapy could induce an effective HER2-specific humoral and T cell-mediated immunity [89]. In 
another phase I study, an HLA-A2 ${ }^{+}$-matched allogeneic MDA-MB-231 breast cancer cell line was transfected with the costimulatory molecule B7-1 (CD80) and used as a vaccine against stage IV BC [92]. Although no tumor regression was observed, the vaccinated patients did show an increase in tumor-specific immune activity [92]. The data available from clinical trials demonstrate the efficacy of cell-based allogenic vaccines in stimulating a measurable immune response $[93,94]$. The safety of an allogeneic vaccine was investigated in a clinical trial sponsored by Paul Ehrlich Institute, Langen, Germany (NCT01127074, Vaccination of Metastatic Breast Cancer Patients With a CD80-modified Allogeneic Cancer Cell Line (KS2422) (KS2422-vacc)) and in another clinical trial sponsored by Beth Israel Deaconess Medical Center (NCY00625755, A Phase I/II Study to Assess the Safety and Efficacy of Vaccinations With Allogenic Dendritic Cells: Autologous Tumor-Derived Cells Subjected to Electrofusion in Patients With AJCC Stage IV Renal Cell Carcinoma) [95]. However, a major problem with the development of allogeneic tumor cell vaccines is the use of cell lines that may not represent the actual antigen repertoire of the tumor.

\section{Dendritic Cell-Based Vaccines}

Dendritic cells (DCs) are highly specialized antigen-presenting cells that can process exogenous and endogenous antigens and present them to $\mathrm{CD} 4^{+} \mathrm{T}$ cells and $\mathrm{CD} 8^{+} \mathrm{T}$ cells, respectively $[96,97]$. DCs are the strongest modulators of primary immune response and can be exploited to generate highly effective DC-based vaccines [98]. Non-active or immature dendritic cells (iDCs) are usually isolated from the peripheral blood of cancer patients. The iDCs are then supplied with tumor-associated antigens (TAAs), recombinant DNA/RNA encoding tumor antigens, or DC/tumor hybrids [99]. The antigen-laden iDCs are then stimulated by exposure to specific cytokines for stimulation/maturation [100]. Stimulated/mature DCs are then infused back into patients wherein they present the cancer antigens to $\mathrm{CD}^{+} / \mathrm{CD}^{+} \mathrm{T}$ cells, thus launching a robust anti-tumor $\mathrm{T}$ cell response [99]. Kugler et al. demonstrated the efficacy of a DC-based vaccine in patients suffering from advanced BC and ovarian cancer. Autologous DCs were pulsed with HER2/neu- or MUC1-derived peptides to generate a DC-based vaccine. Ten patients included in this pilot study showed a strong immunogenic response with no side effects [101]. The lack of side effects when autologous DCs are used for vaccine production can be exploited to generate potent DC-based vaccines for BC. Using an alternative approach, Avigan et al. fused patient-derived tumor cells with autologous DCs to generate fusion cells [102] The fusion cell-based vaccine showed a strong anti-tumor response in patients suffering from metastatic BC and renal cancer [102]. The use of patient-derived tumor cells or cell lysates provides a wide variety of antigens to the immune system, thus facilitating a strong immunogenic response [103]. Zhang et al. generated a whole antigen vaccine against BC by fusing DCs with TNBC cells. The DC-TNBC hybrid was found to potentially elicit anti-tumor immunity by facilitating lymphocyte proliferation [104]. Preclinical studies for the development of DC-based vaccines for BC have shown some promising results. Sakai et al. modified DCs by transducing them with a non-signaling neu oncogene, which thwarted the growth of BC in BALB-neu transgenic mice [105]. A detailed explanation of the clinical studies related to DC-based vaccines has been discussed elsewhere [103].

\section{DNA-Based Vaccines}

Recently, the use of DNA-based vaccines has emerged as an effective vaccination strategy against cancer [106]. DNA vaccines have the potential to induce an antitumor immune response in breast cancer patients [107-109]. DNA vaccines are based on the dogma that the gene encoding a tumor antigen can be transfected and expressed in an APC. Physiologically, such antigens are further processed and presented to launch a strong and viable antitumor immune response. The most important aspects of DNA vaccination are the selection or design of a potent plasmid vector and an efficient delivery system coupled with monitoring of post-vaccination immune response. The plasmid used in DNA vaccines is usually of bacterial origin with CMV or a chimeric SV40-CMV promoter $[110,111]$. 
DNA-based vaccines are designed by using different types of TAAs. The TAAs are usually expressed exclusively in tumors or overexpressed by oncogenes. HER2/neu and mammaglobin-A (Mam-A) are oncoproteins that are overexpressed in breast cancer and have been used as target antigens in developing DNA vaccines. Norell et al. carried out a pilot clinical trial wherein eight patients suffering from advanced/metastatic breast cancer were administered a DNA vaccine containing signaling-deficient full-length version of HER2/neu along with low doses of IL-2 and GM-CSF. A strong humoral response was observed after HER2/neu vaccination, although no substantial improvement in the T cell response was elicited [112]. Mam-A is a 93 amino acid secretoglobin protein that is highly overexpressed in breast cancer and serves as an ideal target antigen. Kim et al. carried out a phase I clinical trial and administered a DNA vaccine carrying Mam-A cDNA to 15 Mam- $\mathrm{A}^{+}$patients, and the post-vaccination immune response was monitored. After six months, the first seven patients enrolled in the study displayed an increase in $\mathrm{ICOS}^{\mathrm{Hi}} \mathrm{CD} 4^{+}$ $\mathrm{T}$ cells and a decrease in Foxp3C CD4C T cells [109]. The activated $\mathrm{ICOS}^{\mathrm{Hi}} \mathrm{CD} 4^{+} \mathrm{T}$ cells expressed IFN- $\gamma$ instead of IL-10 and were observed to cause preferential lysis of MamA-expressing breast cancer cells [113]. The present studies demonstrate the effectiveness of DNA vaccines in controlling breast cancer. However, the safety and the immunogenic mechanisms of DNA-based vaccines need to be further investigated.

\section{Future Direction and Concluding Remarks}

Breast cancer treatment using chemotherapy, hormonal therapy, passive immunotherapy, and other modalities has made a major contribution to the treatment of breast cancer. However, long-lasting effects are limited, and disease relapse and progression are observed in some patients. The discovery of breast cancer as immunogenic and the success of therapeutic vaccines such as Sipuleucel-T in treating prostate cancers raised the prospect of utilizing vaccination to manage breast cancer. Several preclinical studies are ongoing, and many vaccine candidates for treating breast cancers are currently in clinical trials. Some vaccine candidates in the advanced stage of clinical trials are showing promising results in treating breast cancer. The vaccine candidates for managing HER2-positive breast cancers are progressing well with promising results. A single-agent E75 peptide-based vaccine candidate is being studied in a phase III clinical trial and in combination with trastuzumab in a phase II study. Active immunotherapy could be an effective treatment regimen for managing breast cancer along with other therapies such as surgery, radiation, chemotherapy, endocrine therapy, and monoclonal antibodies. Active immunotherapy has the ability to produce antibodies for specific TAA, which promotes long-lasting effects. However, until now, no therapeutic vaccines have been approved by the US FDA for treating breast cancer. The success of cancer vaccines depends on a better understanding of the tumor microenvironment, including immune-suppressing pathways and tumor-evading pathways, the discovery of specific tumor-associated antigens, effective vaccine formulations, etc. There is promising efficacy data regarding the treatment of breast cancer by designing personalized vaccines based on TTAs and genetic mutations. In the case of personalized medicine, effective molecular stratification of breast cancer, vaccine formulation, and costeffective vaccine manufacturing process need to be considered. In addition, clinical trials combining immunotherapy with other treatments that might produce an effective and synergic treatment regimen for breast cancer patients need to be explored.

While therapeutic cancer vaccines have shown some promise, they have not shown significant clinical benefits compared to immunotherapy such as immune checkpoint blockade. Hence, combination strategies with immune checkpoint inhibitors and antiangiogenic therapies have been proposed. Clinical trials consisting of large cohorts of patients are necessary to evaluate therapeutic efficacy of the proposed vaccine therapies [33]. Considering the cost of cancer drugs and the survival rate, mutation of proteins that are involved in cancer development, and resistance pathways, therapeutic vaccines have promise in the future of cancer therapy. 
Author Contributions: Conceptualization: S.P. and S.J. Resources: S.P.; A.R.M.A.; J.C.; S.J. WritingOriginal draft preparation: S.P. and A.R.M.A. Writing-review and editing: S.J.; S.P.; A.R.M.A.; J.C. Project administration: S.J. All authors contributed to the writing or editing of the review. All authors have read and agreed to the published version of the manuscript.

Funding: Seetharama Jois was supported by funding from the National Institute of General Medical Sciences of the National Institute of Health under grant number P20GM103424-18.

Institutional Review Board Statement: Not applicable.

Informed Consent Statement: Not applicable.

Data Availability Statement: Not applicable.

Conflicts of Interest: The authors declare no conflict of interest.

\section{Abbreviations}

ADCC antibody-dependent cell-mediated cytotoxicity

APCs antigen-presenting cells

ATCVs autologous tumor cell-based vaccines

BC breast cancer

CMV cytomegalovirus

COX-2 cyclooxygenase 2

CTL cytotoxic T lymphocytes

CY cyclophosphamide

DCs dendritic cells

DOX doxorubicin

ECD extracellular domain

EGFR epidermal growth factor receptor

ER estrogen receptor

FDA Food and Drug Administration

GM-CSF macrophage colony-stimulating factor

HER human epidermal growth factor receptor

HLA human leukocyte antigen

hTERT telomerase reverse transcriptase

ICD intracellular domain

ICOS inducible T-cell costimulator

iDCs immature dendritic cells

IDO1 indoleamine 2,3-dioxygenase 1

IFN- $\gamma \quad$ interferon gamma

IHC immunohistochemistry

mCRPC metastatic castrate-resistant prostate cancer

M-CSF macrophage-colony stimulating factor

MDSCs myeloid-derived suppressor cells

MHC major histocompatibility complex

mRNA messenger RNA

MUC-1 mucin-1

PR progesterone receptor

SLPs synthetic long peptides

TAA tumor-associated antigens

T-DM1 trastuzumab emtansine

TGF transforming growth factor

TNBC triple-negative breast cancer

TSA tumor-specific antigen

VEGF vascular endothelial growth factor

WHO World Health Organization 


\section{References}

1. Ferlay, J.; Colombet, M.; Soerjomataram, I.; Mathers, C.; Parkin, D.M.; Pineros, M.; Znaor, A.; Bray, F. Estimating the global cancer incidence and mortality in 2018: GLOBOCAN sources and methods. Int. J. Cancer 2019, 144, 1941-1953. [CrossRef] [PubMed]

2. Bray, F.; Ferlay, J.; Soerjomataram, I.; Siegel, R.L.; Torre, L.A.; Jemal, A. Global cancer statistics 2018: GLOBOCAN estimates of incidence and mortality worldwide for 36 cancers in 185 countries. CA Cancer J. Clin. 2018, 68, 394-424. [CrossRef] [PubMed]

3. Siegel, R.L.; Miller, K.D.; Jemal, A. Cancer statistics, 2020. CA Cancer J. Clin. 2020, 70, 7-30. [CrossRef]

4. Khuwaja, A.K.; Rafique, G.; White, F.; Azam, S.I. Macrovascular complications and their associated factors among persons with type 2 diabetes in Karachi, Pakistan-A multi-center study. JPMA J. Pak. Med. Assoc. 2004, 54, 60-66.

5. Logan, G.J.; Dabbs, D.J.; Lucas, P.C.; Jankowitz, R.C.; Brown, D.D.; Clark, B.Z.; Oesterreich, S.; McAuliffe, P.F. Molecular drivers of lobular carcinoma in situ. Breast Cancer Res. 2015, 17, 76. [CrossRef]

6. Arteaga, C.L.; Sliwkowski, M.X.; Osborne, C.K.; Perez, E.A.; Puglisi, F.; Gianni, L. Treatment of HER2-positive breast cancer: Current status and future perspectives. Nat. Rev. Clin. Oncol. 2011, 9, 16-32. [CrossRef]

7. Li, G.; Guo, J.; Shen, B.Q.; Yadav, D.B.; Sliwkowski, M.X.; Crocker, L.M.; Lacap, J.A.; Phillips, G.D.L. Mechanisms of Acquired Resistance to Trastuzumab Emtansine in Breast Cancer Cells. Mol. Cancer Ther. 2018, 17, 1441-1453. [CrossRef] [PubMed]

8. Hynes, N.E.; Lane, H.A. ERBB receptors and cancer: The complexity of targeted inhibitors. Nat. Rev. Cancer 2005, 5, 341-354. [CrossRef]

9. $\quad$ Ross, J.S.; Slodkowska, E.A.; Symmans, W.F.; Pusztai, L.; Ravdin, P.M.; Hortobagyi, G.N. The HER-2 receptor and breast cancer: Ten years of targeted anti-HER-2 therapy and personalized medicine. Oncologist 2009, 14, 320-368. [CrossRef]

10. Ross, J.S.; Fletcher, J.A. The HER-2/neu Oncogene in Breast Cancer: Prognostic Factor, Predictive Factor, and Target for Therapy. Stem Cells 1998, 16, 413-428. [CrossRef]

11. Recondo, G.; Diaz Canton, E.; de la Vega, M.; Greco, M.; Recondo, G.; Valsecchi, M.E. Therapeutic options for HER-2 positive breast cancer: Perspectives and future directions. World J. Clin. Oncol. 2014, 5, 440-454. [CrossRef] [PubMed]

12. Wolmark, N.; Wang, J.; Mamounas, E.; Bryant, J.; Fisher, B. Preoperative chemotherapy in patients with operable breast cancer: Nine-year results from National Surgical Adjuvant Breast and Bowel Project B-18. J. Natl. Cancer Inst. Monogr. 2001, 96-102. [CrossRef] [PubMed]

13. Van der Hage, J.A.; van de Velde, C.J.; Julien, J.P.; Tubiana-Hulin, M.; Vandervelden, C.; Duchateau, L. Preoperative chemotherapy in primary operable breast cancer: Results from the European Organization for Research and Treatment of Cancer trial $10902 . J$. Clin. Oncol. 2001, 19, 4224-4237. [CrossRef] [PubMed]

14. Asselain, B.; Barlow, W.; Bartlett, J.; Bergh, J.; Bergsten-Nordström, E.; Bliss, J.; Boccardo, F.; Boddington, C.; Bogaerts, J.; Bonadonna, G.; et al. Long-term outcomes for neoadjuvant versus adjuvant chemotherapy in early breast cancer: Meta-analysis of individual patient data from ten randomised trials. Lancet Oncol. 2018, 19, 27-39. [CrossRef]

15. Cameron, D.; Piccart-Gebhart, M.J.; Gelber, R.D.; Procter, M.; Goldhirsch, A.; de Azambuja, E.; Castro, G., Jr.; Untch, M.; Smith, I.; Gianni, L.; et al. 11 years' follow-up of trastuzumab after adjuvant chemotherapy in HER2-positive early breast cancer: Final analysis of the HERceptin Adjuvant (HERA) trial. Lancet 2017, 389, 1195-1205. [CrossRef]

16. Hirayama, M.; Nishimura, Y. The present status and future prospects of peptide-based cancer vaccines. Int. Immunol. 2016, 28, 319-328. [CrossRef]

17. Weiner, L.M. Building better magic bullets-improving unconjugated monoclonal antibody therapy for cancer. Nat. Rev. Cancer 2007, 7, 701-706. [CrossRef]

18. Humphries, C. Adoptive cell therapy: Honing that killer instinct. Nature 2013, 504, S13-S15. [CrossRef]

19. Molina, M.A.; Codony-Servat, J.; Albanell, J.; Rojo, F.; Arribas, J.; Baselga, J. Trastuzumab (herceptin), a humanized anti-Her2 receptor monoclonal antibody, inhibits basal and activated Her2 ectodomain cleavage in breast cancer cells. Cancer Res. 2001, 61, 4744-4749.

20. Spector, N.L.; Blackwell, K.L. Understanding the mechanisms behind trastuzumab therapy for human epidermal growth factor receptor 2-positive breast cancer. J. Clin. Oncol. 2009, 27, 5838-5847. [CrossRef]

21. Baselga, J.; Albanell, J.; Molina, M.A.; Arribas, J. Mechanism of action of trastuzumab and scientific update. Semin. Oncol. 2001, 28, 4-11. [CrossRef]

22. Martin, M.; Lopez-Tarruella, S. Emerging Therapeutic Options for HER2-Positive Breast Cancer. In American Society of Clinical Oncology Educational Book; American Society of Clinical Oncology: Alexandria, VA, USA, 2016; pp. e64-e70.

23. Verma, S.; Miles, D.; Gianni, L.; Krop, I.E.; Welslau, M.; Baselga, J.; Pegram, M.; Oh, D.Y.; Dieras, V.; Guardino, E.; et al. Trastuzumab emtansine for HER2-positive advanced breast cancer. N. Engl. J. Med. 2012, 367, 1783-1791. [CrossRef] [PubMed]

24. Von Minckwitz, G.; Huang, C.S.; Mano, M.S.; Loibl, S.; Mamounas, E.P.; Untch, M.; Wolmark, N.; Rastogi, P.; Schneeweiss, A.; Redondo, A.; et al. Trastuzumab Emtansine for Residual Invasive HER2-Positive Breast Cancer. N. Engl. J. Med. 2019, 380, 617-628. [CrossRef] [PubMed]

25. Modi, S.; Saura, C.; Yamashita, T.; Park, Y.H.; Kim, S.B.; Tamura, K.; Andre, F.; Iwata, H.; Ito, Y.; Tsurutani, J.; et al. Trastuzumab Deruxtecan in Previously Treated HER2-Positive Breast Cancer. N. Engl. J. Med. 2020, 382, 610-621. [CrossRef] [PubMed]

26. Tamura, K.; Tsurutani, J.; Takahashi, S.; Iwata, H.; Krop, I.E.; Redfern, C.; Sagara, Y.; Doi, T.; Park, H.; Murthy, R.K.; et al. Trastuzumab deruxtecan (DS-8201a) in patients with advanced HER2-positive breast cancer previously treated with trastuzumab emtansine: A dose-expansion, phase 1 study. Lancet Oncol. 2019, 20, 816-826. [CrossRef] 
27. Bettaieb, A.; Paul, C.; Plenchette, S.; Shan, J.; Chouchane, L.; Ghiringhelli, F. Precision medicine in breast cancer: Reality or utopia? J. Transl. Med. 2017, 15, 139. [CrossRef]

28. Lollini, P.-L.; Cavallo, F.; Nanni, P.; Forni, G. Vaccines for tumour prevention. Nat. Rev. Cancer 2006, 6, 204. [CrossRef]

29. Currie, G.A. Eighty years of immunotherapy: A review of immunological methods used for the treatment of human cancer. Br. J. Cancer 1972, 26, 141-153. [CrossRef]

30. Arab, A.; Yazdian-Robati, R.; Behravan, J. HER2-Positive Breast Cancer Immunotherapy: A Focus on Vaccine Development. Arch. Immunol. Ther. Exp. 2020, 68, 2. [CrossRef]

31. Arigoni, M.; Barutello, G.; Lanzardo, S.; Longo, D.; Aime, S.; Curcio, C.; Iezzi, M.; Zheng, Y.; Barkefors, I.; Holmgren, L. A vaccine targeting angiomotin induces an antibody response which alters tumor vessel permeability and hampers the growth of established tumors. Angiogenesis 2012, 15, 305-316. [CrossRef]

32. Butterfield, L.H. Cancer vaccines. BMJ 2015, 350, h988. [CrossRef] [PubMed]

33. Banchereau, J.; Palucka, K. Immunotherapy: Cancer vaccines on the move. Nat. Rev. Clin. Oncol. 2018, 15, 9. [CrossRef] [PubMed]

34. Clifton, G.T.; Gall, V.; Peoples, G.E.; Mittendorf, E.A. Clinical development of the E75 vaccine in breast cancer. Breast Care 2016, 11, 116-121. [CrossRef] [PubMed]

35. Thomas, S.; Prendergast, G.C. Cancer vaccines: A brief overview. In Vaccine Design; Springer: Berlin/Heidelberg, Germany, 2016; pp. 755-761.

36. Ye, Z.; Qian, Q.; Jin, H.; Qian, Q. Cancer vaccine: Learning lessons from immune checkpoint inhibitors. J. Cancer 2018, 9, 263. [CrossRef]

37. Perez, C.R.; De Palma, M. Engineering dendritic cell vaccines to improve cancer immunotherapy. Nat. Commun. 2019, 10, 1-10. [CrossRef]

38. Lopes, A.; Vandermeulen, G.; Préat, V. Cancer DNA vaccines: Current preclinical and clinical developments and future perspectives. J. Exp. Clin. Cancer Res. 2019, 38, 146. [CrossRef]

39. De Giovanni, C.; Landuzzi, L.; Palladini, A.; Ianzano, M.L.; Nicoletti, G.; Ruzzi, F.; Amici, A.; Croci, S.; Nanni, P.; Lollini, P.-L. Cancer vaccines co-targeting her2/neu and igf1r. Cancers 2019, 11, 517. [CrossRef]

40. Gatti-Mays, M.E.; Redman, J.M.; Collins, J.M.; Bilusic, M. Cancer vaccines: Enhanced immunogenic modulation through therapeutic combinations. Hum. Vaccines Immunother. 2017, 13, 2561-2574. [CrossRef]

41. Pan, R.Y.; Chung, W.H.; Chu, M.T.; Chen, S.J.; Chen, H.C.; Zheng, L.; Hung, S.I. Recent Development and Clinical Application of Cancer Vaccine: Targeting Neoantigens. J. Immunol. Res. 2018, 2018, 4325874. [CrossRef]

42. Hollingsworth, R.E.; Jansen, K. Turning the corner on therapeutic cancer vaccines. NPJ Vaccines 2019, 4, 7. [CrossRef]

43. Costa, R.L.B.; Czerniecki, B.J. Clinical development of immunotherapies for HER2(+) breast cancer: A review of HER2-directed monoclonal antibodies and beyond. NPJ Breast Cancer 2020, 6, 10. [CrossRef] [PubMed]

44. Al-Awadhi, A.; Lee Murray, J.; Ibrahim, N.K. Developing anti-HER2 vaccines: Breast cancer experience. Int. J. Cancer 2018, 143, 2126-2132. [CrossRef] [PubMed]

45. Stanton, S.E.; Disis, M.L. Designing vaccines to prevent breast cancer recurrence or invasive disease. Immunotherapy 2015, 7, 69-72. [CrossRef] [PubMed]

46. Anderson, K.S. Tumor vaccines for breast cancer. Cancer Investig. 2009, 27, 361-368. [CrossRef] [PubMed]

47. Chew, V.; Toh, H.C.; Abastado, J.-P. Immune microenvironment in tumor progression: Characteristics and challenges for therapy. J. Oncol. 2012. [CrossRef]

48. Zou, W. Immunosuppressive networks in the tumour environment and their therapeutic relevance. Nat. Rev. Cancer 2005, 5, 263. [CrossRef]

49. Gabrilovich, D.I. Myeloid-derived suppressor cells. Cancer Immunol. Res. 2017, 5, 3-8. [CrossRef]

50. Gurusamy, D.; Clever, D.; Eil, R.; Restifo, N.P. Novel “elements” of immune suppression within the tumor microenvironment. Cancer Immunol. Res. 2017, 5, 426-433. [CrossRef]

51. Tanaka, A.; Sakaguchi, S. Regulatory T cells in cancer immunotherapy. Cell Res. 2017, 27, 109. [CrossRef]

52. Burkholder, B.; Huang, R.-Y.; Burgess, R.; Luo, S.; Jones, V.S.; Zhang, W.; Lv, Z.-Q.; Gao, C.-Y.; Wang, B.-L.; Zhang, Y.-M. Tumor-induced perturbations of cytokines and immune cell networks. Biochim. Biophys. Acta (BBA)-Rev. Cancer 2014, 1845, 182-201. [CrossRef]

53. Flint, T.R.; Janowitz, T.; Connell, C.M.; Roberts, E.W.; Denton, A.E.; Coll, A.P.; Jodrell, D.I.; Fearon, D.T. Tumor-induced IL-6 reprograms host metabolism to suppress anti-tumor immunity. Cell Metab. 2016, 24, 672-684. [CrossRef] [PubMed]

54. Timosenko, E.; Hadjinicolaou, A.V.; Cerundolo, V. Modulation of cancer-specific immune responses by amino acid degrading enzymes. Immunotherapy 2017, 9, 83-97. [CrossRef] [PubMed]

55. Wilcox, R.A.; Tamada, K.; Flies, D.B.; Zhu, G.; Chapoval, A.I.; Blazar, B.R.; Kast, W.M.; Chen, L. Ligation of CD137 receptor prevents and reverses established anergy of CD8+ cytolytic T lymphocytes in vivo. Blood 2004, 103, 177-184. [CrossRef] [PubMed]

56. Bansal-Pakala, P.; Jember, A.G.-H.; Croft, M. Signaling through OX40 (CD134) breaks peripheral T-cell tolerance. Nat. Med. 2001, 7, 907. [CrossRef] [PubMed]

57. Saxena, M.; Bhardwaj, N. Re-Emergence of Dendritic Cell Vaccines for Cancer Treatment. Trends Cancer 2018, 4, 119-137. [CrossRef]

58. Tiwary, S.; Berzofsky, J.A.; Terabe, M. Altered Lipid Tumor Environment and Its Potential Effects on NKT Cell Function in Tumor Immunity. Front. Immunol. 2019, 10, 2187. [CrossRef] 
59. Disis, M.L.; Pupa, S.M.; Gralow, J.R.; Dittadi, R.; Menard, S.; Cheever, M.A. High-titer HER-2/neu protein-specific antibody can be detected in patients with early-stage breast cancer. J. Clin. Oncol. 1997, 15, 3363-3367. [CrossRef]

60. Nelde, A.; Rammensee, H.G.; Walz, J.S. The peptide vaccine of the future. Mol. Cell. Proteom. 2020. [CrossRef]

61. Calvo Tardon, M.; Allard, M.; Dutoit, V.; Dietrich, P.Y.; Walker, P.R. Peptides as cancer vaccines. Curr. Opin. Pharmacol. 2019, 47, 20-26. [CrossRef]

62. Hos, B.J.; Tondini, E.; van Kasteren, S.I.; Ossendorp, F. Approaches to Improve Chemically Defined Synthetic Peptide Vaccines. Front. Immunol. 2018, 9, 884. [CrossRef]

63. Wiedermann, U.; Davis, A.B.; Zielinski, C.C. Vaccination for the prevention and treatment of breast cancer with special focus on Her-2/neu peptide vaccines. Breast Cancer Res. Treat. 2013, 138, 1-12. [CrossRef] [PubMed]

64. Fisk, B.; Blevins, T.L.; Wharton, J.T.; Ioannides, C.G. Identification of an immunodominant peptide of HER-2/neu protooncogene recognized by ovarian tumor-specific cytotoxic T lymphocyte lines. J. Exp. Med. 1995, 181, 2109-2117. [CrossRef]

65. Kono, K.; Takahashi, A.; Sugai, H.; Fujii, H.; Choudhury, A.R.; Kiessling, R.; Matsumoto, Y. Dendritic cells pulsed with HER2/neu-derived peptides can induce specific T-cell responses in patients with gastric cancer. Clin. Cancer Res. 2002, 8, 3394-3400. [PubMed]

66. Kawashima, I.; Hudson, S.J.; Tsai, V.; Southwood, S.; Takesako, K.; Appella, E.; Sette, A.; Celis, E. The multi-epitope approach for immunotherapy for cancer: Identification of several CTL epitopes from various tumor-associated antigens expressed on solid epithelial tumors. Hum. Immunol. 1998, 59, 1-14. [CrossRef]

67. Mittendorf, E.A.; Lu, B.; Melisko, M.; Hiller, J.P.; Bondarenko, I.; Brunt, A.M.; Sergii, G.; Petrakova, K.; Peoples, G.E. Efficacy and Safety Analysis of Nelipepimut-S Vaccine to Prevent Breast Cancer Recurrence: A Randomized, Multicenter, Phase III Clinical Trial. Clin. Cancer Res. 2019, 25, 4248-4254. [CrossRef] [PubMed]

68. Ayoub, N.M.; Al-Shami, K.M.; Yaghan, R.J. Immunotherapy for HER2-positive breast cancer: Recent advances and combination therapeutic approaches. Breast Cancer Targets Ther. 2019, 11, 53. [CrossRef] [PubMed]

69. Mittendorf, E.A.; Ardavanis, A.; Litton, J.K.; Shumway, N.M.; Hale, D.F.; Murray, J.L.; Perez, S.A.; Ponniah, S.; Baxevanis, C.N.; Papamichail, M. Primary analysis of a prospective, randomized, single-blinded phase II trial evaluating the HER2 peptide GP2 vaccine in breast cancer patients to prevent recurrence. Oncotarget 2016, 7, 66192. [CrossRef]

70. Clifton, G.T.; Mittendorf, E.A.; Peoples, G.E. Adjuvant HER2/neu peptide cancer vaccines in breast cancer. Immunotherapy 2015, 7, 1159-1168. [CrossRef]

71. Wiedermann, U.; Wiltschke, C.; Jasinska, J.; Kundi, M.; Zurbriggen, R.; Garner-Spitzer, E.; Bartsch, R.; Steger, G.; Pehamberger, H.; Scheiner, O. A virosomal formulated Her-2/neu multi-peptide vaccine induces Her-2/neu-specific immune responses in patients with metastatic breast cancer: A phase I study. Breast Cancer Res. Treat. 2010, 119, 673-683. [CrossRef]

72. Bekaii-Saab, T.; Wesolowski, R.; Ahn, D.H.; Wu, C.; Mortazavi, A.; Lustberg, M.; Ramaswamy, B.; Fowler, J.; Wei, L.; Overholser, J.; et al. Phase I Immunotherapy Trial with Two Chimeric HER-2 B-Cell Peptide Vaccines Emulsified in Montanide ISA 720VG and Nor-MDP Adjuvant in Patients with Advanced Solid Tumors. Clin. Cancer Res. 2019, 25, 3495-3507. [CrossRef]

73. Milani, A.; Sangiolo, D.; Montemurro, F.; Aglietta, M.; Valabrega, G. Active immunotherapy in HER2 overexpressing breast cancer: Current status and future perspectives. Ann. Oncol. 2013, 24, 1740-1748. [CrossRef] [PubMed]

74. Li, W.; Joshi, M.D.; Singhania, S.; Ramsey, K.H.; Murthy, A.K. Peptide Vaccine: Progress and Challenges. Vaccines 2014, 2, 515-536. [CrossRef] [PubMed]

75. Malonis, R.J.; Lai, J.R.; Vergnolle, O. Peptide-Based Vaccines: Current Progress and Future Challenges. Chem. Rev. 2020, 120, 3210-3229. [CrossRef] [PubMed]

76. Zhang, H.; Hong, H.; Li, D.; Ma, S.; Di, Y.; Stoten, A.; Haig, N.; Di Gleria, K.; Yu, Z.; Xu, X.N.; et al. Comparing pooled peptides with intact protein for accessing cross-presentation pathways for protective CD8+ and CD4+ T cells. J. Biol. Chem. 2009, 284, 9184-9191. [CrossRef] [PubMed]

77. Costa, R.L.B.; Soliman, H.; Czerniecki, B.J. The clinical development of vaccines for HER2(+) breast cancer: Current landscape and future perspectives. Cancer Treat. Rev. 2017, 61, 107-115. [CrossRef] [PubMed]

78. Rosalia, R.A.; Quakkelaar, E.D.; Redeker, A.; Khan, S.; Camps, M.; Drijfhout, J.W.; Silva, A.L.; Jiskoot, W.; van Hall, T.; van Veelen, P.A.; et al. Dendritic cells process synthetic long peptides better than whole protein, improving antigen presentation and T-cell activation. Eur. J. Immunol. 2013, 43, 2554-2565. [CrossRef]

79. Disis, M.L.; Schiffman, K.; Guthrie, K.; Salazar, L.G.; Knutson, K.L.; Goodell, V.; Dela Rosa, C.; Cheever, M.A. Effect of dose on immune response in patients vaccinated with an her-2/neu intracellular domain protein-based vaccine. J. Clin. Oncol. 2004, 22, 1916-1925. [CrossRef]

80. Knutson, K.L.; Schiffman, K.; Disis, M.L. Immunization with a HER-2/neu helper peptide vaccine generates HER-2/neu CD8 T-cell immunity in cancer patients. J. Clin. Investig. 2001, 107, 477-484. [CrossRef]

81. Hamilton, E.; Blackwell, K.; Hobeika, A.C.; Clay, T.M.; Broadwater, G.; Ren, X.-R.; Chen, W.; Castro, H.; Lehmann, F.; Spector, N. Phase I clinical trial of HER2-specific immunotherapy with concomitant HER2 kinase inhibtion. J. Transl. Med. $2012,10,28$. [CrossRef]

82. Foy, T.M.; Fanger, G.R.; Hand, S.; Gerard, C.; Bruck, C.; Cheever, M.A. Designing HER2 vaccines. Semin. Oncol. 2002, 29 , 53-61. [CrossRef]

83. Kurtz, S.L.; Ravindranathan, S.; Zaharoff, D.A. Current status of autologous breast tumor cell-based vaccines. Expert Rev. Vaccines 2014, 13, 1439-1445. [CrossRef] [PubMed] 
84. Mellman, I.; Coukos, G.; Dranoff, G. Cancer immunotherapy comes of age. Nature 2011, 480, 480. [CrossRef] [PubMed]

85. Simons, J.W.; Jaffee, E.M.; Weber, C.E.; Levitsky, H.I.; Nelson, W.G.; Carducci, M.A.; Lazenby, A.J.; Cohen, L.K.; Finn, C.C.; Clift, S.M. Bioactivity of autologous irradiated renal cell carcinoma vaccines generated by ex vivo granulocyte-macrophage colony-stimulating factor gene transfer. Cancer Res. 1997, 57, 1537-1546. [PubMed]

86. Ahlert, T.; Sauerbrei, W.; Bastert, G.; Ruhland, S.; Bartik, B.; Simiantonaki, N.; Schumacher, J.; Hacker, B.; Schumacher, M.; Schirrmacher, V. Tumor-cell number and viability as quality and efficacy parameters of autologous virus-modified cancer vaccines in patients with breast or ovarian cancer. J. Clin. Oncol. 1997, 15, 2763. [CrossRef]

87. Jiang, X.P.; Yang, D.C.; Elliott, R.L.; Head, J.F. Vaccination with a mixed vaccine of autogenous and allogeneic breast cancer cells and tumor associated antigens CA15-3, CEA and CA125-results in immune and clinical responses in breast cancer patients. Cancer Biother. Radiopharm. 2000, 15, 495-505. [CrossRef]

88. Elliott, R.L.; Head, J.F. Adjuvant breast cancer vaccine improves disease specific survival of breast cancer patients with depressed lymphocyte immunity. Surg. Oncol. 2013, 22, 172-177. [CrossRef]

89. Emens, L.A.; Asquith, J.M.; Leatherman, J.M.; Kobrin, B.J.; Petrik, S.; Laiko, M.; Levi, J.; Daphtary, M.M.; Biedrzycki, B.; Wolff, A.C. Timed sequential treatment with cyclophosphamide, doxorubicin, and an allogeneic granulocyte-macrophage colony-stimulating factor-secreting breast tumor vaccine: A chemotherapy dose-ranging factorial study of safety and immune activation. J. Clin. Oncol. 2009, 27, 5911. [CrossRef]

90. Philip, P.A.; Mooney, M.; Jaffe, D.; Eckhardt, G.; Moore, M.; Meropol, N.; Emens, L.; O’Reilly, E.; Korc, M.; Ellis, L. Consensus report of the national cancer institute clinical trials planning meeting on pancreas cancer treatment. J. Clin. Oncol. 2009, 27, 5660-5669. [CrossRef]

91. Mehta, R.; Schubbert, T.; Hsiang, D.; Butler, J.; Baick, C.; Su, M. High pathological complete remission rates with paclitaxel and carboplatin \pm trastuzumab $(\mathrm{TC} \pm \mathrm{H})$ following dose dense doxorubicin and cyclophosphamide (AC) supported by GM-CSF in breast cancer-a phase II study. Breast Cancer Res. Treat. 2005, 94, 225.

92. Dols, A.; Smith, J.W.; Meijer, S.L.; Fox, B.A.; Hu, H.-M.; Walker, E.; Rosenheim, S.; Moudgil, T.; Doran, T.; Wood, W. Vaccination of women with metastatic breast cancer, using a costimulatory gene (CD80)-modified, HLA-A2-matched, allogeneic, breast cancer cell line: Clinical and immunological results. Hum. Gene Ther. 2003, 14, 1117-1123. [CrossRef]

93. Srivatsan, S.; Patel, J.M.; Bozeman, E.N.; Imasuen, I.E.; He, S.; Daniels, D.; Selvaraj, P. Allogeneic tumor cell vaccines: The promise and limitations in clinical trials. Hum. Vaccines Immunother. 2014, 10, 52-63. [CrossRef] [PubMed]

94. Guckel, B.; Stumm, S.; Rentzsch, C.; Marme, A.; Mannhardt, G.; Wallwiener, D. A CD80-transfected human breast cancer cell variant induces HER-2/neu-specific T cells in HLA-A*02-matched situations in vitro as well as in vivo. Cancer Immunol. Immunother. 2005, 54, 129-140. [CrossRef] [PubMed]

95. Avigan, D.E.; Vasir, B.; George, D.J.; Oh, W.K.; Atkins, M.B.; McDermott, D.F.; Kantoff, P.W.; Figlin, R.A.; Vasconcelles, M.J.; Xu, Y.; et al. Phase I/II study of vaccination with electrofused allogeneic dendritic cells/autologous tumor-derived cells in patients with stage IV renal cell carcinoma. J. Immunother. 2007, 30, 749-761. [CrossRef] [PubMed]

96. Steinman, R.M. The dendritic cell system and its role in immunogenicity. Annu. Rev. Immunol. 1991, 9, 271-296. [CrossRef]

97. Mempel, T.R.; Henrickson, S.E.; Von Andrian, U.H. T-cell priming by dendritic cells in lymph nodes occurs in three distinct phases. Nature 2004, 427, 154-159. [CrossRef]

98. Palucka, K.; Banchereau, J. Dendritic-cell-based therapeutic cancer vaccines. Immunity 2013, 39, 38-48. [CrossRef]

99. Garg, A.D.; Vara Perez, M.; Schaaf, M.; Agostinis, P.; Zitvogel, L.; Kroemer, G.; Galluzzi, L. Trial watch: Dendritic cell-based anticancer immunotherapy. Oncoimmunology 2017, 6, e1328341. [CrossRef]

100. Anguille, S.; Smits, E.L.; Bryant, C.; Van Acker, H.H.; Goossens, H.; Lion, E.; Fromm, P.D.; Hart, D.N.; Van Tendeloo, V.F.; Berneman, Z.N. Dendritic cells as pharmacological tools for cancer immunotherapy. Pharmacol. Rev. 2015, 67, 731-753. [CrossRef]

101. Kugler, A.; Stuhler, G.; Walden, P.; Zöller, G.; Zobywalski, A.; Brossart, P.; Trefzer, U.; Ullrich, S.; Müller, C.A.; Becker, V. Regression of human metastatic renal cell carcinoma after vaccination with tumor cell-dendritic cell hybrids. Nat. Med. 2000, 6, 332-336. [CrossRef]

102. Avigan, D.; Vasir, B.; Gong, J.; Borges, V.; Wu, Z.; Uhl, L.; Atkins, M.; Mier, J.; McDermott, D.; Smith, T. Fusion cell vaccination of patients with metastatic breast and renal cancer induces immunological and clinical responses. Clin. Cancer Res. 2004, 10, 4699-4708. [CrossRef]

103. Gelao, L.; Criscitiello, C.; Esposito, A.; Laurentiis, M.D.; Fumagalli, L.; Locatelli, M.A.; Minchella, I.; Santangelo, M.; Placido, S.D.; Goldhirsch, A. Dendritic cell-based vaccines: Clinical applications in breast cancer. Immunotherapy 2014, 6, 349-360. [CrossRef] [PubMed]

104. Zhang, P.; Yi, S.; Li, X.; Liu, R.; Jiang, H.; Huang, Z.; Liu, Y.; Wu, J.; Huang, Y. Preparation of triple-negative breast cancer vaccine through electrofusion with day-3 dendritic cells. PLoS ONE 2014, 9, e102197. [CrossRef] [PubMed]

105. Sakai, Y.; Morrison, B.J.; Burke, J.D.; Park, J.-M.; Terabe, M.; Janik, J.E.; Forni, G.; Berzofsky, J.A.; Morris, J.C. Vaccination by genetically modified dendritic cells expressing a truncated neu oncogene prevents development of breast cancer in transgenic mice. Cancer Res. 2004, 64, 8022-8028. [CrossRef] [PubMed]

106. Ferraro, B.; Morrow, M.P.; Hutnick, N.A.; Shin, T.H.; Lucke, C.E.; Weiner, D.B. Clinical applications of DNA vaccines: Current progress. Clin. Infect. Dis. 2011, 53, 296-302. [CrossRef] [PubMed] 
107. Nguyen-Hoai, T.; Kobelt, D.; Hohn, O.; Vu, M.D.; Schlag, P.M.; Dörken, B.; Norley, S.; Lipp, M.; Walther, W.; Pezzutto, A. HER2/neu DNA vaccination by intradermal gene delivery in a mouse tumor model: Gene gun is superior to jet injector in inducing CTL responses and protective immunity. Oncoimmunology 2012, 1, 1537-1545. [CrossRef]

108. Bharat, A.; Benshoff, N.; Fleming, T.P.; Dietz, J.R.; Gillanders, W.E.; Mohanakumar, T. Characterization of the role of CD8+ T cells in breast cancer immunity following mammaglobin-A DNA vaccination using HLA-class-I tetramers. Breast Cancer Res. Treat. 2008, 110, 453-463. [CrossRef]

109. Kim, S.W.; Goedegebuure, P.; Gillanders, W.E. Mammaglobin-A is a target for breast cancer vaccination. Oncoimmunology 2016, 5, e1069940. [CrossRef]

110. Manthorpe, M.; Cornefert-Jensen, F.; Hartikka, J.; Felgner, J.; Rundell, A.; Margalith, M.; Dwarki, V. Gene therapy by intramuscular injection of plasmid DNA: Studies on firefly luciferase gene expression in mice. Hum. Gene Ther. 1993, 4, 419-431. [CrossRef]

111. Williams, J.A.; Carnes, A.E.; Hodgson, C.P. Plasmid DNA vaccine vector design: Impact on efficacy, safety and upstream production. Biotechnol. Adv. 2009, 27, 353-370. [CrossRef]

112. Norell, H.; Poschke, I.; Charo, J.; Wei, W.Z.; Erskine, C.; Piechocki, M.P.; Knutson, K.L.; Bergh, J.; Lidbrink, E.; Kiessling, R. Vaccination with a plasmid DNA encoding HER-2/neu together with low doses of GM-CSF and IL-2 in patients with metastatic breast carcinoma: A pilot clinical trial. J. Transl. Med. 2010, 8, 53. [CrossRef]

113. Tiriveedhi, V.; Fleming, T.P.; Goedegebuure, P.S.; Naughton, M.; Ma, C.; Lockhart, C.; Gao, F.; Gillanders, W.E.; Mohanakumar, T. Mammaglobin-A cDNA vaccination of breast cancer patients induces antigen-specific cytotoxic CD4+ ICOS hi T cells. Breast Cancer Res. Treat. 2013, 138, 109-118. [CrossRef] [PubMed] 